ロ絵 2 : 写真で見るスイス・ローヌ氷河の後退史

\title{
Pictorial 2 : History of Retreat of the Rhone Glacier Recorded Photographically
}

スイスの中央部に位置するローヌ氷河は，スイス・アルプスのなかでも 19 世紀以来急速に後退している氷河の一つである その様子を写真と最新の資料により紹介する（本文 127 ～ 135 参照．

The Rhone Glacier is one of the rapidly retreating glaciers in the Swiss Alps. Photographs taken in various years record its history of retreat (Text p. 127-135).

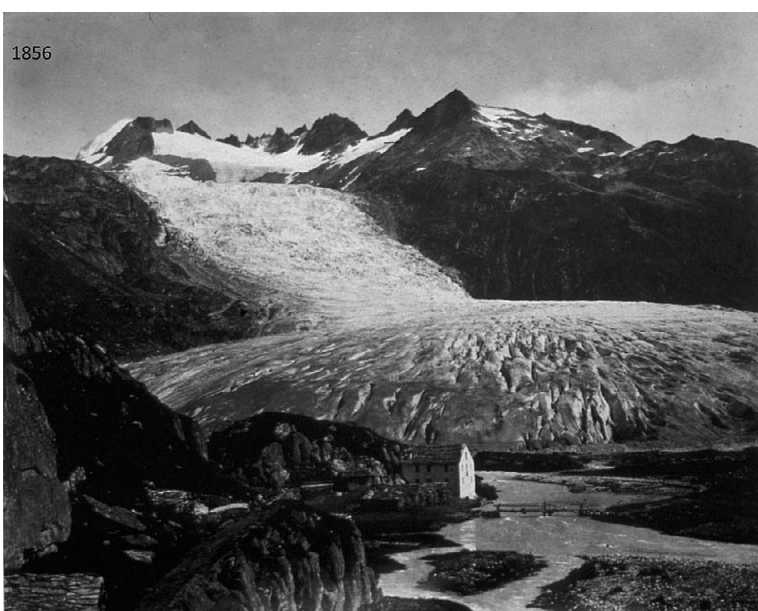

図 1 前進中のローヌ氷河の末端に到達した運動波（1856 年）

Fig. 1 Kinematic wave approaching the advancing front (1856).

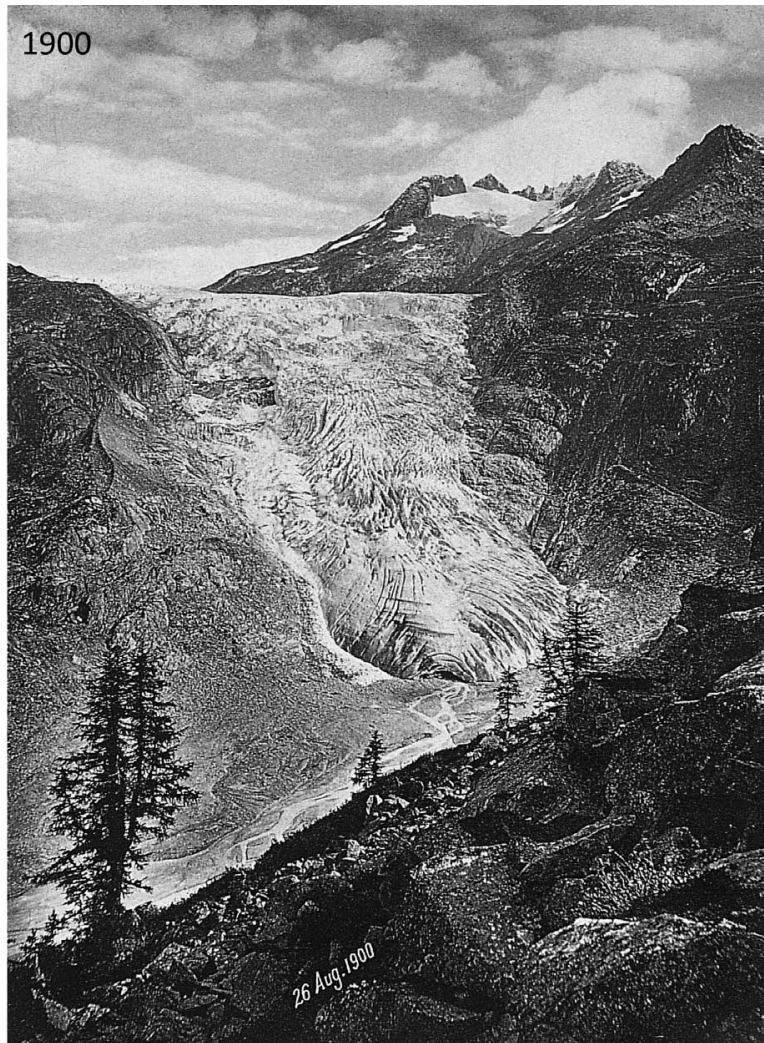

図 3 後退したローヌ氷河 (1900 年)。急斜面下の谷底に末 端が届いている

Fig. 3 Retreating Rhone Glacier, just reaching the face of the cliff (1900)

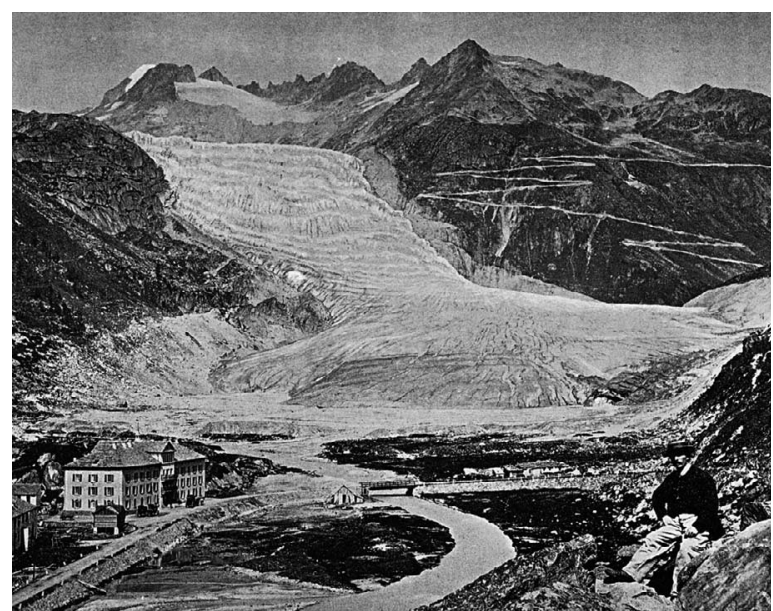

図 2 後退中の再前進 (1870 年)

Fig. 2 Slight re-advance (1870).

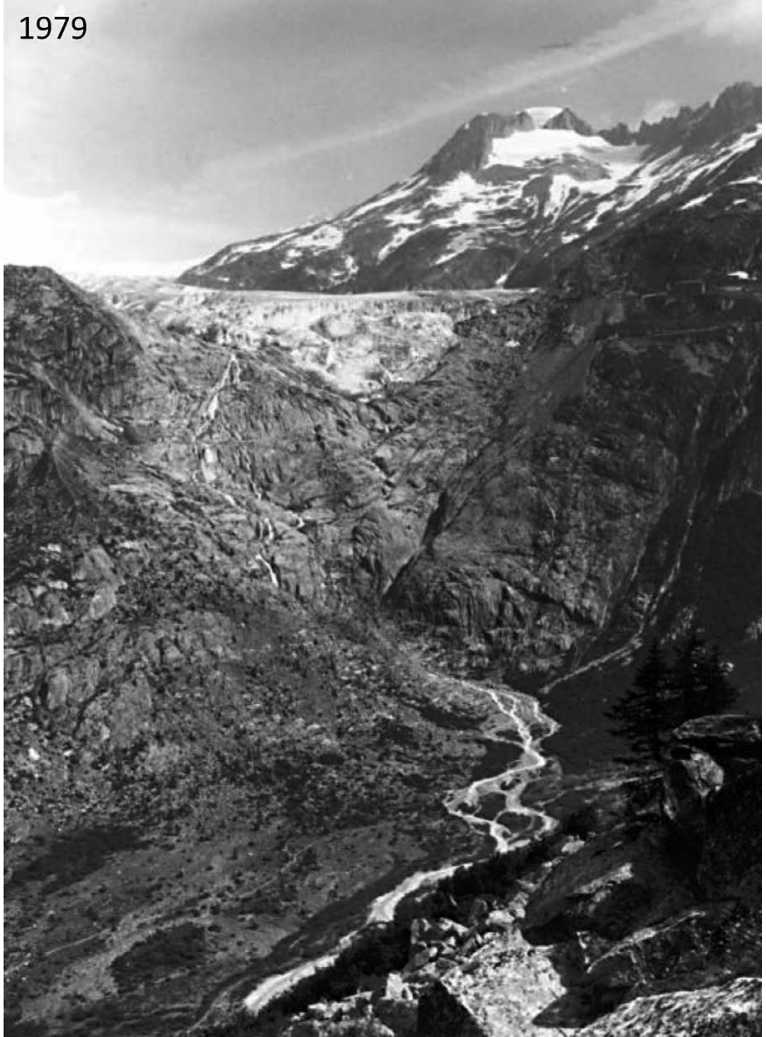

図 4 末端部が急斜面の上部まで後退（1979 年)。

Fig. 4 Front has retreated to the top of the cliff (1979).

図 1 〜 の写真はスイス国立工科大学地理学教室, 図 4 は Dr. Moser, U. による。

Fig. 1-3 were taken by Geographisches Institute, ETH and Fig. 4 was taken by Dr. U. Moser. 
ロ絵 2（つづき）：写真で見るスイス・ローヌ氷河の後退史

\section{Pictorial 2 : History of Retreat of the Rhone Glacier Recorded Photographically}

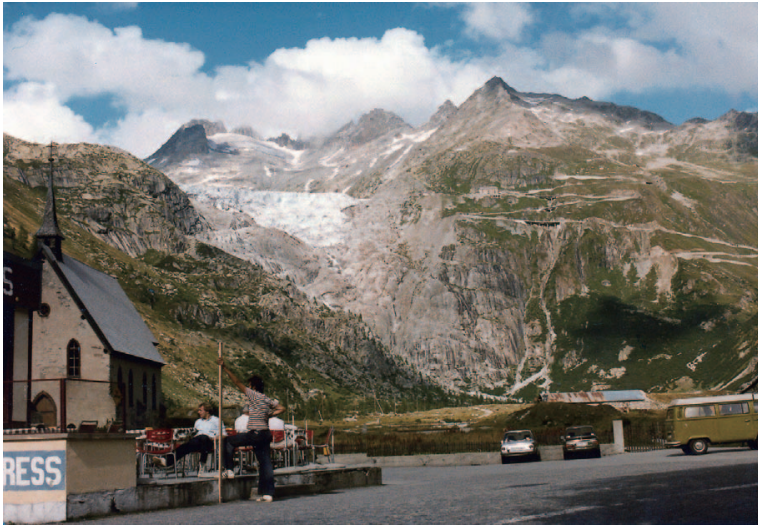

図 5 さらに後退するローヌ氷河 (1983 年 9 月).

Fig. 5 Glacier continues its retreat (September, 1983).

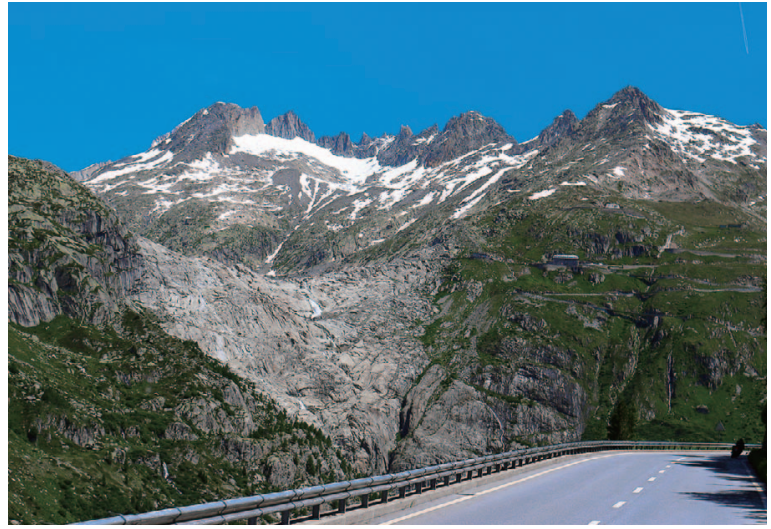

図 6 急崖から完全に消えたローヌ氷河（2014 年 7 月）.

Fig. 6 Rhone Glacier disappeared completely from the steep cliff (July, 2014).

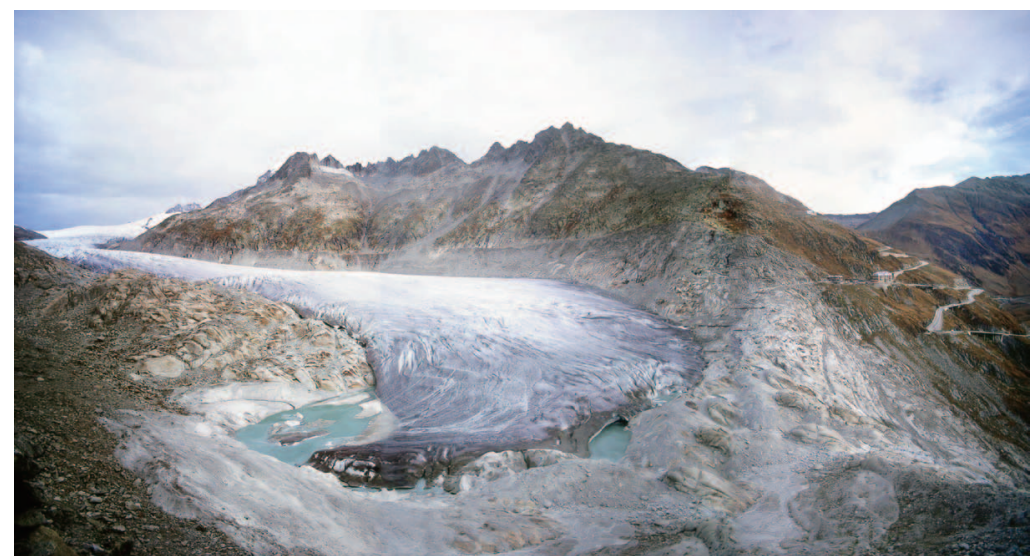

図 72006 年にローヌ氷河の末端に出現した 2 つの湖（2006 年スイス国立工科大学水理氷河研究所撮影）.

Fig. 7 Twin glacier-dammed lakes appeared in 2006. Photograph taken by VAW, ETH.

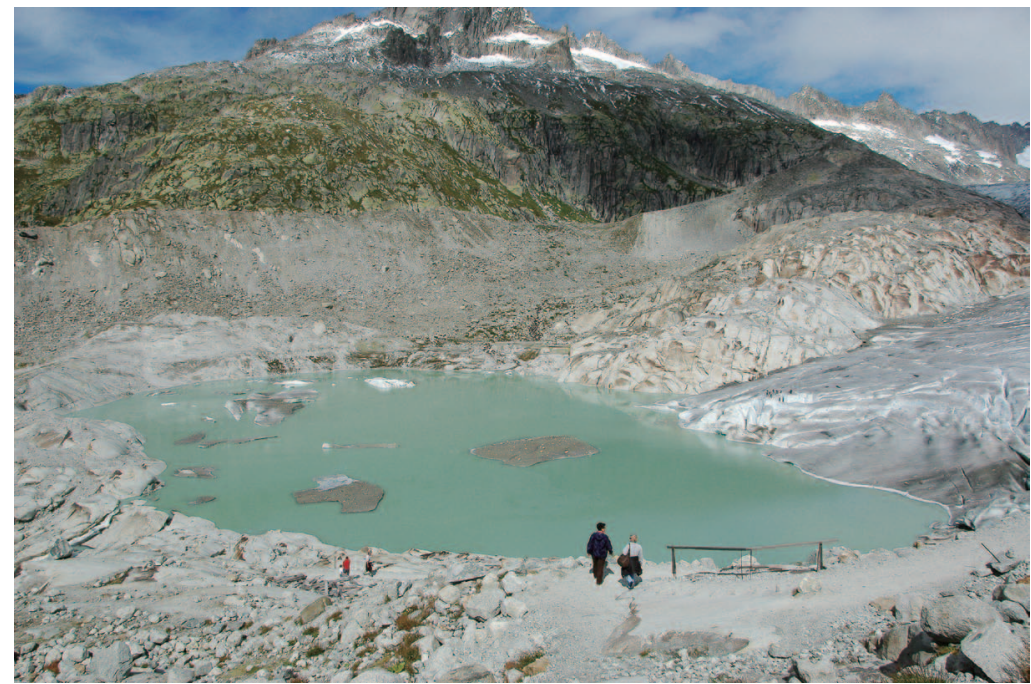

図 82 つの湖が 2011 年に合体，さらに拡大するローヌ湖（2014 年 9 月）.

Fig. 8 After the twin lakes merged in 2011, Rhonesee continued to grow (September, 2014). 